\title{
CONTRACTS FOR THE BENEFIT OF THIRD PERSONS ${ }^{1}$
}

\author{
ARTHUR L. CORBIN \\ Professor of Law, Yale University
}

By the great weight of authority in the United States the same facts that operate to create contractual relations between the offeror and the acceptor may also operate to create rights in a third person. ${ }^{2}$ It may be useful, therefore, to examine in detail the nature and limits of this doctrine and to classify and discuss the cases in distinct groups.

To many students and practitioners of the common law privity of contract became a fetish. As such, it operated to deprive many a claimant of a remedy in cases where according to the mores of the time the claim was just. It has made many learned men believe that a chose in action could not be assigned. Even now, it is gravely asserted that a man cannot be made the debtor of another against his will. But the common law was gradually infuenced by equity and by the law merchant, so that by assignment a debtor could become bound to pay a perfect stranger to himself, although until the legislature stepped in, the common-law courts characteristically made use of a fiction and pretended that they were not doing that which they really were doing.

\section{TRUST BENEFICIARIES}

If without privity of contract, one may become indebted to another, the lack of privity is surely no reason for denying him a beneficial right. As usual, equity saw this long before the common law did."

\footnotetext{
1 This article contains the substance of certain sections in an edition of Anson on Contracts to be published by the Oxford University Press. Some use has been made of the notes of Professor E. W. Huffcut in an earlier edition.

${ }^{2}$ See I3 C. J. 705, sec. 815, citing more than 350 cases; 6 R. C. L. 884 , sec. 271 ; Wald's Pollock, Contracts (Williston's ed. 1906) 237-278.

'In order that privity of contract may exist, it seems to be necessary for $A$ to say to B "I promise you." It requires the voluntary selection of each party by the other. See criticism of the term privity in I5 AM. LAw Rev. 244-5. For recent adherence to the fetish, see $6 \mathrm{R}$. C. L. $885, \mathrm{sec} .271$.

- Not alone in the cases of trustee and cestui que trust was this true. The court did not shrink from expanding the concept of a trust to cover the case of a contract beneficiary. See Tomlinson v. Gill (1756) Ambler, 330, before Hardwicke, L. C.; Moore v. Darton (I85I) 4 DeG. \& Sm. 517. See also School District v. Livers (1899) 147 Mo. 580; Forbes v. Thorpe (19II) 209 Mass. 570; Grime v. Borden (1896) 166 Mass. Ig8; Nash v. Commonwealth (1899) 174 Mass. 335.
} 
No privity is necessary to create rights in a cestui que trust, and no consideration need move from him. If it was possible and desirable for equity to recognize the very extensive rights, powers, privileges, and immunities of a cestui que trust, it is equally possible, and it appears to the American courts to be equally desirable, to recognize similar relations betwen a promisor and a contractual beneficiary. It is no answer to say that in the one case the magic words "in trust" were used, while in the latter they were not. This would be mere fetish worship once more. It may be that the rights, powers, privileges, and immunities of a cestui que trust are more numerous and valuable than are those of a contract beneficiary. The cestui que trust, without privity and without giving value, gets so much;should not the contract beneficiary be given at least a crumb?

It may be argued that in the case of trust there is a specific res, while in the case of the contract there is not. This is also a distinction that proves nothing. Suppose there is a specific physical res-its mere existence is no reason for creating rights in a beneficiary without privity and without value given by him. In many cases of trust, however, there is no physical res. The trust res is then said to consist of the rights and powers of the trustee, which he "holds" in trust and must exercise for the benefit of the cestui que trust. If such an unreal res may be the basis of rights in a beneficiary, there is no greater difficulty in the case of contract.

The reasons for recognizing rights in the contract beneficiary are substanitially the same as those underlying the rights of a cestui que trust. By so doing the intention of the parties is carried out and the beneficiary's just expectations are fulfilled. The reason is not, as has sometimes been suggested, that the promisee was acting as the agent of the third party: He was not in fact so acting and nobody supposed that he was. Nor is the beneficiary's right to be explained on some theory of subrogation.

POSSESSION OF ASSETS BY THE PROMISOR

In nearly all of the American jurisdictions, including those that deny a right of action to most third party beneficiaries, there is one sort of beneficiary who is given a right of action. "Where, under a

\footnotetext{
'See Pennsylvania Steel Co. v. New York City R. Co. (19I2) Ig8 Fed. 721, 749. Lord Mansfield in Martyn v. Hind (1776) Cowp. 437, 443, said it was a matter of surprise how a doubt could have arisen in a case like Dutton $v$. Poole (1677) 2 Lev. 210.

- See opinion of Johnson, C. J., and Denio, J., in Lawrence v. Fox (1859) 20 N. Y. 268; Union Inst. v. Phoenix Ins. Co. (I907) I96 Mass. 230. In accord with the text is the opinion of Finch J., in Gifford $v$. Corrigan (I889) II7 N. Y. 257.

${ }^{7}$ See discussion below in connection with mortgagee-beneficiaries.
} 
contract between two persons, assets have come to the promisor's hands or under his control which in equity belong to a third person," the beneficiary can maintain an action at law in his own name. ${ }^{8}$ These cases essentially recognize that a beneficiary can acquire a legal right without privity and without giving consideration. In some such cases a true equitable trust may exist with respect to some specific res. In most such cases, however, this is not so. If there is a trust and a specific res, the duty of the promisor should be held to be merely the duty to account. The fact is that the duty enforced against the promisor is that of a debtor. ${ }^{\circ}$ Some of these cases may properly be regarded as based upon the quasi-contractual doctrine of unjust enrichment, in which case the defendant's duty is limited by the value received by him. By the great majority of courts, however, it is regarded as unjust for the promisor not to perform as he promised in return for a consideration; and the beneficiary's right is dependent upon neither a specific res nor an unjust enrichment, but upon the existence of a valid contract. ${ }^{10}$

\section{PLAINTIFF A PROMISEE, BUT CONSIDERATION GIVEN BY ANOTHER}

In some cases the promise is made to the plaintiff, but the consideration moves from.a third party. Here the plaintiff is a promisee and there is no lack of privity. The problem is merely one as to con-

${ }^{5}$ See National Bark v. Grand Lodge (1878) 98 U. S. I23; Hall v. Marston (1822) I7 Mass. 575; Fitch v. Chandler (1849, Mass.) 4 Cush. 254; Mellen v. Whipple (1854, Mass.) I Gray, 317; Exchange Bank v. Rice (1871) I07 Mass. 37. And see cases cited in 13 C. J. 704, secs. 809, 810. A recent Massachusetts case says that the plaintiff's right is "in equity"; but this does not affect the character of the right and the duty, for the defendant is treated as a debtor and not as a trustee. Forbes v. Thorpe (IgII) 209 Mass. 570. Cf. Borden v. Boardman (I82) I57 Mass. 410. A remedy at law was denied in Morgan v. Randolph \& Clowes Co. (1900) 73 Conn. 396.

The "assets" here referred to are assets in the hands of the promisor and do not include the promise itself, which is sometimes rcgarded as an asset of the promisee.

- For example, where a devise given on condition that a certain sum be paid to a beneficiary is accepted by the devisee, the latter is a debtor of the beneficiary irrespective of the value of the devise Felch $v$. Taylor (1832, Mass.) I3 Pick. 133; Adams v. Adams (1867, Mass.) 14 Allen, 65; Olmstead v. Brush (1858) 27 Conn. 530; Brown v. Knapp (1879) 79 N. Y. 136; Flickinger v. Saum (I884) 40 Oh. St. 591; Porter v. Jackson (1884) 95 Ind. 210; LaValle v. Droit (1913) I79 Ill. Ápp. 484; Etier v. Greenawalt (I88I) $98 \mathrm{~Pa}$. 422 . See.also Feldman v. McGuire (1899) 34 Ore. 309.

20 The plaintiff's action, therefore, may be assumpsit for unliquidated damages as well as debt for a specific sum. His action lies also where the defendant has assumed to settle a claim for unliquidated damages that the plaintiff had against the promisee. Likewise the beneficiary has been given an injunction for the enforcement of a negative covenant Ferris v. Amer. Brewirig Co. (1900) I55 Ind. 539. 
sideration. It is the English law that the consideration must move from the promisee. ${ }^{11}$ Such is not the American law as. generally laid down by our courts, ${ }^{12}$ and some of the cases draw a clear distinction between a promise to the plaintiff upon a consideration moving from another ${ }^{13}$ and a promise to $\mathrm{X}$ for the benefit of the plaintiff upon a consideration moving from $X$. In some cases the promise seems to be made simultaneously to both the plaintiff and the one furnishing the consideration. ${ }^{14}$ Where a promise is made to two persons jointly, it seems not to be questioned whether the consideration must move from both. No doubt a fiction is indulged and the joint promisees are regarded as a unity. Where the beneficiary is. not himself the promisee, he can always establish a sufficient "privity" to satisfy the courts by obtaining an assignment from the promisee. He will then possess whatever rights the promisee had as well as such rights as a beneficiary as may be recognized in the particular jurisdiction. ${ }^{15}$

\section{DONEE-BENEFICIARIES AND SOLE BENEFICLARIES}

In many cases the purpose of the promisee in securing a promise for the benefit of a third party is to confer a gratuitous benefit upon that third party. In such cases this third party will usually be the only person who will be benefited by the promised performance; he will be the sole beneficiary. ${ }^{18}$ Performance will not benefit the promisee; he is not to receive it, and such performance will not discharge any duty of the promisee, for he owes none to the beneficiary. If the purpose is to discharge some duty owed by the promisee to the third party, the latter is not a donee.

"Dunlop v. Selfridge [I9r5] A. C. 847.

${ }^{1}$ Van Eman v. Stanchfield (1879) 10 Minn. 255; Rector v. Teed (1890) I20 N. Y. 583; Palmer Sav. Bk. v. Insurance Co. (I896) 166 Mass. I89. See also Gardner v. Denison (IgI4) 217 Mass. 492.

${ }^{23}$ In First N. B. v. Chalmers (I895) I44 N. Y. 432, 439, the court says:

"I do not deem the doctrine of Lawence v. Fox (1859) 20 N. Y. 268 involved in this controversy. That doctrine applies where no express promise has been made to the party suing, but he claims the right to rest upon a promise between other parties having respect to the debt due to him and as having been made for his benefit. It struggles to obviate a lack of privity upon equitable principles, but is neediess and has no proper application where the privity exists, and a direct promise has been made upon which the action may rest."

See also De Cicco v. Schweizer (I9I7, N. Y.) II7 N. E. 807, and the dissenting opinion of Comstock, J., in Lawrence v. Fox (1859) 20 N. Y. 268.

"Bouton v. Welch (1902) 170 N. Y. 554; Furbish v. Goodnow (I867) 98 Mass. 296.

${ }^{15}$ Hyland v. Crofut (1913) 87 Conn. 49; Reed v. Paul (I88I) I3I Mass. 129; Litchfield v. Flint (1887) 104 N. Y. 543; Societa Italiana v. Sulzer (I893) I38 N. Y. 468.

${ }^{10}$ The plaintiff may be a donee-beneficiary even though he is not the sole beneficiary. In such case he can maintain suit. Jenkins $v$. Chesapeake \& O.R. Co. (I907) 6r W. Va. 597 . 
It is clear that a sole beneficiary should be allowed to enforce the contract, and great numbers of cases have so held. ${ }^{17}$ It was once suggested by the United States Supreme Court ${ }^{18}$ that a sole beneficiary was the only kind who could sue, on the ground that to allow a creditor-beneficiary to sue would subject the promisor to two suits for breach. ${ }^{18}$ On the other hand, the New York courts long repeated the rule that no beneficiary could sue unless he was a creditor (or an obligee) of the promisee. ${ }^{20}$ Neither of these limitations, contradictory to each other as they are, should be sustained.

Some cases have decided in favor of a donee-beneficiary on the ground of a relationship by blood or marriage between the beneficiary and the promisee. ${ }^{21}$ Such relationship is an evidential fact showing

${ }^{17}$ In re Edmundson's Estate (1918, Pa.) I03 Atl. 277; Rogers v. Galloway Female College (I8g8) 64 Ark. 627 (beneficiary of a charitable subscription); St. Louis v. Von Phul (I895) I33 Mo. 56I ; Todd v. Weber (1884) 95 N. Y. I8I (promise to the mother of plaintiff to furnish support. See other cases of this type in note 2I infra); Whitehead v. Burgess (1897) 6I N. J. L. 75; Bouton v. IV clch (1902) I70 N. Y. 554; Pond v. New Rochelle W. Co. (1906) I83 N. Y. 330 (promise to a village for the benefit of the inhabitants); Rigney $v$. New York Central R. R. Co. (IgI6) 217 N. Y. 3I (same); Smyth v. New York (IgII) 203 N. Y. 106 (same); Independent Sch. Dist. v. Le Mars Water Co. (1906) 131 Iowa, 14; Doll v. Crume (I894) 4I Neb. 655; Gorrell v. Water Co. (1899) I24 N. C. 328 ; Tweeddale v. Tweeddale (I903) I16 Wis. 517; Simors v. Bedell (1898) $122 \mathrm{Cal} 34 \mathrm{I}$ (specific performance decreed). Contra, Kuights of the Maccabees v. Sharp (1910) I63 Mich. 449. See further 22 L. R. A. (N. S.) 492 ; 39 L. R. A. (N. S.) 151 ; 49 L. R. A. (N. S.) II66.

${ }^{28}$ National Bank v. Grand Lodge (1878) $98 \mathrm{U}$. S. 123. By statute, this rule seems to prevail in the Virginias. Newberry Land Co. v. Newberry (1897) 95 Va. 119; King v. Scoti (1915) $76 \mathrm{~W}$. Va. 58.

${ }^{20}$ The rights of the promisee will be discussed below.

${ }^{20}$ King v. Whitely (1843, N. Y.) 1o Paige, 465 [but see Thorp v. Keokuk \& Co. (1872) 48 N. Y. 253]; Vrooman v. Turner (I877) 69 N. Y. 280; Durnherr v. Rau (1892) I35 N. Y. 219; Jefferson v. Asch (1893) 53 Minn. 446. Their substantial abandonment of this doctrine will be indicated below. Nevertheless the doctrine continues to influence the decisions in many states in certain classes of cases. See the sections below on "Mortgagee-beneficiaries" and "Liability of Water Companies."

${ }^{11}$ Dutton v. Poole (1677) 2 Lev. 210; In re Edmundson's Estate (I918, Pa.) I03 Atl. 277; Daily v. Mirtnick (1902) II7 Iowa, 563; Benge v. Hiatt (I885) 82 Ky. 666; Schemerhorn v. Vanderheyden (1806, N. Y.) I Johns, 139; Todd v. Weber, supra; Coleman v. Whitney (1889) 62 Vt. I23. Contra, Linneman v. Moross (1893) 98 Mich. 178.

In the following cases, it is believed, the relationship by blood or marriage caused the court to strain the facts and to hold, contrary to the fact, that the beneficiary was also a promisee: DeCicco v. Schweizer (I917, N. Y.) II7 N. E. 807; Gardner v. Denison (I914) 217 Mass. 492; Eaton v. Libbey (1896) 165 Mass. 218; Freeman v. Morris (Ig07) 13I Wis. 216. In the following cases such relationship caused the court to hold that the promisee owed the beneficiary a legal or an equitable duty when in fact there was none: Buchanan v. Tilden (1899) 158 N. Y. I09; Seaver v. Ransom (I917, App. Div.) I68 N. Y. Supp. $454 C f$. Opper v. Hirsh (Ig0I) 68 N. Y. Supp. $8799^{\bullet}$ 
that the promisee truly intended that the third party should receive a benefit, and indicates the causa-the reason or motive-for which he paid the consideration. But the intention to benefit the third party can be clearly shown by the express words of the contract, or by other evidence, and relationship should not be held to be a necessary operative fact. ${ }^{22}$

In life insurance the beneficiary is usually a sole beneficiary, and in all jurisdictions he can maintain suit on the policy. In England and a few of our states, this result was attained by statute. ${ }^{23}$ It would indeed create a scandal to deny him a right of action either because he was not the promisee or because he gave no consideration.

\section{CREDITOR-BENEFICIARIES}

Where the third party is a creditor of the promisee, or has a right against him for some particular performance, the purpose with which the promisee contracts with the promisor may be to induce the latter to pay the debt or otherwise to discharge the third party's claim. In such case, performance will directly benefit both the third party (the creditor or claimant) and the promisee. The third party is not a donee and is not a sole beneficiary. Although not the first case of the sort, the famous case of Lawrence $v$. Fo $x^{24}$ is now regarded as the leading authority to the effect that a creditor-beneficiary has an enforceable right. Here a money debt of $\$ 300$ was owed by Holly to Lawrence, and he had that sum ready to be paid. Fox borrowed the money over night, promising Holly to pay the debt to Lawrence next day. It was held that Lawrence could maintain suit against Fox to enforce this promise. For a good many years this decision was severely criticised, the critics being obsessed with the idea that privity was logically necessary. Fine distinctions were often drawn so as to avoid following this decision, but in spite of some confusion thus caused, the great weight of authority is in harmony with it and a creditor-beneficiary can maintain suit. ${ }^{25}$

\footnotetext{
= It now seems to be assumed to be the settled law of England that blood relationship will not enable a beneficiary to sue. Tweddle v. Atkinsor (I86r) I B. \& S. 393.

2In Massachusetts the beneficiary's right has been said to be in equity only. Nims v. Ford (1893) I59 Mass. 575. It is not apparent on casual inspection why the procedural statute, R. I. 1902, C. I59, sec. 8 , should not sustain an action of "contract."

2" (1859) 20 N. Y. 268.

“Bohanan v. Pope (1856) 42 Me. 93; Joslin v. New Jersey Car Spring Co. (1873) 36 N. J. L. I4I; Barker v. Bucklin (1846, N. Y.) 2 Den. 45; Wood v. Moriarty ( 1887 ) I5 R. I. 518; Zell's Appeal (1886) III Pa. 532, 547; Ballard v. Home Nat'l. Bark (1913) 91 Kan. 91, L. R. A. Ig16 C, I6I, and note. See 25 L. R. A. 257 , note; $x_{3}$ C. J. 705 , sec. $8 x_{5}$, citing hundreds of cases.

Where a new partner enters a firm and promises the old members to pay a
} 


\section{MORTGAGEE-BENERICIARTES}

One of the most frequent cases where a third party attempts to enforce a contract on the theory that he is a beneficiary is that of a mortgagee. A mortgagee is nearly always to be regarded as the creditor of somebody, but he may not be the creditor of the promisee. Where a mortgagor who is himself personally indebted sells his interest in the property mortgaged to a grantee who assumes payment of the mortgage debt, the mortgagee is a creditor-beneficiary, and he is almost universally allowed to maintain suit against the grantee and to get a personal judgment against him for the amount of the debt. ${ }^{28}$

share of the previous debts he may properly be sued by the creditors. Arnold $v$. Nichols (1876) 64 N. Y. II7; Lehoze v. Simonton (1877) 3 Colo. 346; Dunlap v. McNeil (1871) 35 Ind. 316; Floyd v. Ort (1878) $20 \mathrm{Kan}$ 162; Hannigan v. Allen (I89I) I27 N. Y. 639; Clafin v. Ostrom (1874) 54 N. Y. 58I; Maxfield v. Schwartz (I890) 43 Minn. 221 ; i3 C. J. 709 . It was once held that a promise to pay one-half or some other fraction of all the previous debts cannot be enforced by any creditor because no single creditor can well show that it is for his benefit. Wheat v. Rice (1884) 97 N. Y. 296; Serviss v. McDonnell (1887) 107 N. Y. 260; distinguished in Hannigan.v. Allen, supra. Contra: Johnson v. McClung (1885) $26 \mathrm{~W}$. Va. 659.

Where a mortgagor insures premises and the policy is made payable to the mortgagee as his interest may appear, the mortgagee can sue the insurer. Union Inst. v. Phoenix Ins. Co. (I907) I96 Mass. 230 (on theory of agency); Palmer Savings Bank v. Ins. Co. (1896) 166 Mass. 189. Contra: Minnock v. Eureka F. \& M.I. Co. (I\&g2) 90 Mich. 236.

Where a municipality owes a duty to travellers to keep a street in repair and makes a contract with the defendant for the latter to do this, a traveller who is injured can sue the defendant by virtue of this contract. Jenree $v$. Metrop. St. Ry. Co. (rgiz) 86 Kan. 479; McMahon v. Second Ave. R. Co. (I878) 75 N. Y. 23I. See many other cases of this sort cited in 49 L. R. A. (N. S.) II6.6, note.

See further, mortgagee-beneficiary cases, infra.

A very few states still hold that a creditor-beneficiary cannot sue in a common law action. Morgan v. Randolph \& Clowes Co. (1900) 73 Conn. 396; Meller v. Whipple (1854, Mass.) I Gray 317; Exchange Bank v. Rice (1871) 107 Mass. 37 ; Borden v. Boardman (1892) 157 Mass. 410; Minnock v. Eureka F. \& M. I. Co. (1892) go Mich. 236; Edwards v. Thoman (1915) I87 Mich. $36 \mathrm{I}$; National Bank v. Grand Lodge (1878) 98 U. S. 123.

${ }^{20}$ Gifford v. Corrigan (1889) II7 N. Y. 257; Thorp v. Keokuk Coal.Co. (1872) 48 N. Y. 253, 257; Burr v. Beers (I86I) 24 N. Y. 178; Gay v. Blanchard (I880) 32 La. Ann. 497 ; Pope v. Porter (1887) 33 Fed. 7 ; Urquhart v. Brayton (I878) 12 R. I. 169; Carver v. Eads (1880) 65 Ala. 190; Allen v. Bucknam (1883) 75 Me. 352; Figart v. Halderman (1881) 75 Ind. 567; Huyler v. Atwood (I875) 26 N. J. Eq. 504; George v. Andrews (I882) $60 \mathrm{Md}$. 26; Cooper v. Foss (I884) I5 Neb. 5I5. Cortra in the Virginias, where by statute only a sole beneficiary can sue: Newberry Land Co. v. Newberry (1897) 95 Va. II9; King v. Scott (I9I5) $76 \mathrm{~W}$. Va. 58.

See, further, cases cited in I3 C. J. 707, sec. 816. In Michigan and Connecticut a mortgagee-beneficiary can sue by virtue of a special statute. Mich. Comp. Laws 1897, sec. 519; Corning v. Burtor (1894) I02 Mich. 86; Conn. G. S. I902, sec. 587 . 
Suppose, however, that the mortgagor sells his interest to a grantee who buys subject to the mortgage but who makes no promise whatever to pay the mortgage debt. He does not "assume the mortgage debt." In such a case, the grantee's rights in rem are limited by the mortgage, ${ }^{27}$ but he undertakes no duty to pay the debt. The mortgagee, therefore, can maintain no action against him, and neither can the grantor. Such a grantee, however, has in numerous cases sold his interest to a second grantee and has caused the latter to assume payment of the mortgage debt. There is here an express promise the performance of which requires a payment directly to the mortgagee. The first grantee is the promisee, and he will not be benefited at all by the payment. So far as the promisee is concerned, therefore, the mortgagee seems to be a mere donee-beneficiary and the sole beneficiary. At this point the decisions are found to be hopelessly at variance. ${ }^{28}$ Those holding that the mortgagee can sue the promisor in these cases seem to be more nearly consistent with the weight of authority in other beneficiary cases. Those holding the contrary generally do so on the ground that a third party cannot enforce a contract unless the performance will operate not only as a benefit to him, but also as the fulfillment of a legal or an equitable duty owing by the promisee to him. This rule was laid down during the period when many of the courts desired to limit the application of the rule of Lawrence $v$. Fox. ${ }^{29}$ It denies all donee-beneficiaries a remedy, and is being abandoned..$^{30}$

Some of the cases denying the mortgagee a remedy under these circumstances rest upon the theory that a beneficiary's right is based upon the equitable doctrine of subrogation. It is generally held in equity that a creditor is not only entitled to sue his principal debtor and all collateral sureties and to realize on such securities as may have been charged with the debt, but also to make use of all securities

\footnotetext{
IT The grantee lacks many rights and immunities because of the mortgage; he has certain "no-rights" because the mortgagee has privileges, and he has liabilities because the mortgagee has powers.

* The mortgagee can sue: McDonald v. Finseth (1915) 32 N. D. 400 ; Casselman v. Gordon (I9I6) II8 Va. 553; Llewellyn v. Butler (IgI5) I86 Mo. 525 ; Thorp v. Keokuk Coal Co., supra. Dean v. Walker (I883) Io7 IIl. 540; Marble Sav. Bank v. Mesarvey (I897) Ior Iowa, 285; Crone v. Stinde (1900) $156 \mathrm{Mo.}$ 262; Hare v. Murphy (I895) 45 Neb. 809; McKay v. Ward (1899) 20 Utah, 149; also many other cases in accord, cited, in Fry v. Ausman, infra.

Contra: Fry v. Ausman (1912) 29 S. D. 30; 39 L. R. A. (N. S.) 150, citing many other cases; Vrooman v. Turner (1877) 69 N. Y. 280 ; Ward v. DeOca (1898) I20 Cal. ro2. See note in 22 L. R. A. (N. S.) 492.

2Jefferson v. Asch (1893) 53 Minn. 446; Viooman v. Turner (1877) 69 N. Y. 280 ; Durnherr v. Rau (I892). I35 N. Y. 219 .

"See discussion of donee-beneficicries, ante; also post, "New York Law." Modern decisions are: Buchanan v. Tilden (1899) 158 N. Y. 109; Pond v. New Rochelle Water Co. (1906) 183 N. Y. 330; De Cicco v. Schweizer (1917, N. Y.) II7 N. E. 807; Gardner v. Denison (Igr4) 217 Mass. 492
} 
that the principal debtor may have given to the surety for the indemnity of the latter..$^{31}$ It is also held that where one assumes the debt of another, although the latter is not thereby discharged, he occupies thereafter the position of a surety and the new promisor occupies the position of a principal debtor. Thus where the promisee is himself indebted to the mortgagee, but has become, under the above theory, a mere surety by reason of his contract with the new promisor, the courts may resort to the doctrine of subrogation and sustain an action by the mortgagee against the promisor because the promisee could have maintained such an action. On the other hand, if the promisee is not himself bound to pay the debt, he is not a surety and the doctrine of subrogation is not applicable.

It appears, however, that this is a very doubtful ground upon which to sustain the action of the mortgagee (or other beneficiary) against the promisor. The doctrine of subrogation has no doubt been very beneficial in spite of fiction and artificiality; but in this instance it has been used to confer new security and new rights upon a creditor, as a gift out of a clear sky. In suretyship it is used only as against one who is already legally indebted in order to secure the fulfillment of that legal duty. A doctrine whose purpose was the enforcement of a previously recognized duty cannot properly be given as the sole reason for creating an entirely new duty. ${ }^{32}$

To rest the beneficiary's right to recover on such a theory as this would shut out all donee (or non-creditor) beneficiaries altogether, yet they are the very persons once thought by the Supreme Court of the United States to be the only beneficiaries who should be permitted to sue on a promise made to another person. ${ }^{33}$ Included among such beneficiaries are most of the persons for whose benefit life insurance policies are issued.

The mortgagee's right against the promisor should rest on the same ground as the right of other beneficiaries. The promisor has under-

"Brandt, Suretyship (3d ed.) sec. 357; Sheldon, Subrogation (2d ed.) sec. 154; Spencer, Surety'ship, sec. 181; Ames, Cases on Suretyship, 620 and note; Keller v. Ashford (1890) ×33 U. S. 610; Hopkins v. Warner (r895) 109 Cal. I33.

= The extension of the subrogation theory to cover this case, where the promisor was not indebted to the third party by reason of any operative fact other than his promise to the promisee, is merely a cumbrous intellectual expedient for holding that a contract between two parties can create an enforceable right in a third. E. g. see Keller v. Ashford (I889) I33 U. S. 6ro, 623.

“See Nat'l Bank v. Grand Lodge (1878) 98 U. S. I23.

The Virginia court regards the fact that the promisee was not bound to pay the debt as showing that the mortgagee was necessarily the "sole beneficiary" within the meaning of the Va. Code, sec. 2415, giving such a beneficiary a remedy. Casselman $v$. Gordon (I916) II8 Va. 553. See also Merriman $v$. Moore (1879) go Pa. 78; Davis v. Davis (1912) I9 Cal. App. 797. Under such a statute it was held that the mortgagee could not sue the grantee of one who was himself personally indebted. King v. Scott (Igr5) 76 W. Va. 58. 
taken for a sufficient consideration to perform an act that will be beneficial to the third party. If such benefit was the contemplated result, and if judgment and execution in favor of the third party will give effect to the intention of the promisor and of the party giving the consideration, there is ample justification for sustaining action by the beneficiary.

Some of the cases denying the mortgagee a remedy may perhaps be justified for the reason that the contracting parties had no intention of benefiting the mortgagee or of conferring a right of action upon him. Indeed, some of them are placed squarely on this ground. ${ }^{34}$ But it is believed that where the promisor has received consideration for a promise the fulfillment of which necessarily requires him to pay money directly to a mortgagee or other third person, it would seem not unreasonable to draw an invariable inference that such third person was contemplated as a beneficiary and as the holder of a new and additional right of action.

\section{INCIDENTAL AND UNINTENDED BENEFICIARIES}

These are persons not intended by the contracting parties to have new rights, and not named as beneficiaries or even as the persons to whom payment is to be made or other performance given. In order that a third party may sue upon a contract made by others he must show that he was intended by them to have an enforceable right or at least that the performance of the contract must necessarily be of benefit to him and such benefit must have been within the contemplation and purpose of the contracting parties. ${ }^{35} \mathrm{He}$ has no right of action where he incidentally finds a provision in some contract which makes to his advantage. On this ground a remedy has, in some instances, been refused to a material man suing on a builder's bond conditioned on paying all claims for material, ${ }^{38}$ and likewise to a

\footnotetext{
"See Fry v. Ausman (Igr2) 29 S. D. 30; King v. Scott (rgr5) 76 W. Va. 58.

* Durnherr v. Rau (I892) I35 N. Y. 2I9; Wheat v. Rice (1884) 97 N. Y. 296; Campbell v. Lacock (I86I) $40 \mathrm{~Pa} 448$; Adams v. Kuehn (1888) II Pa. 76; Miller v. Winchell (1877) 70 N. Y. 437; Case v. Case (I9II) 203 N. Y. 263; Lockwood v. Smith (1913) I43 N. Y. Supp. 480; Thomas Mfg. Co. v. Prather (1898) 65 Ark 27; Buckley v. Gray (1895) 110 Cal. 339. In New Orleans St. J. Assi. v. Magnier (186I) I6 La. Ann. 338, the plaintiff was denied a remedy because performance of the defendant's primary contractual duty would not have benefited the plaintiff, although the plaintiff was expressly named as beneficiary of a penalty clause. This decision should not be followed. See further 13 C. J. 709.

${ }^{\approx}$ Standard Gas Power Corp. v. New England Casualty Co. (I9I7, N. J.) Ior Atl. 281, 27 Yale Law Joural, 274. Cf. School District v. Livers (18g9) 147 Mo. 580. See infra as to statutory provisions. Many cases contra are cited in 49 L. R. A. (N. S.) I166, note.
} 
citizen who sues on a contract between a water company and the municipality. ${ }^{37}$ It is not always easy to determine in fact whether or not the plaintiff was contemplated by the parties as a beneficiary, and much of the apparent conflict in decisions can be explained on this ground. Where the beneficiary is a sole beneficiary, the difficulty does not exist; but in the case of creditor-beneficiaries the question may always be regarded as an open one. If the intention to create a right in a third party is indicated with reasonable certainty, an action by him should be maintainable even though the intention to benefit him was only secondary and conditional, ${ }^{38}$ and irrespective of whether he is a donee or a creditor. Where the agreed performance involves a payment direct to the third party, the enforcement of the contract by him will carry out the intention of the parties.

\section{LIABILITY OF WATER COMPANIES}

Where a water company has contracted with a municipality to maintain a certain supply of water for the putting out of fires and has failed to do so, with the result that the property of an individual citizen has been destroyed, it is very generally held that the citizen has no claim against the water company for breach of contract.30 Various reasons are given for these decisions. Sometimes they are made to rest solely upon the lack of privity, without observing that this is inconsistent with other cases in the same jurisdiction allowing beneficiaries to maintain suit. In other cases it is asserted that the contract was not made for the benefit of the citizens, an assertion that would seem to be generally untrue in fact; and in others it is said that the municipality had no legal power to make such a contract for the benefit of its citizens, a statement that we may be permitted to doubt as a matter of law. Most of the cases denying any right to the citizen have done so for the reason formerly given by the New York courts in all beneficiary cases, to the effect that no beneficiary

$"$ Davis v. Clinton Water Co. (I880) 54 Iowa, 59; Boston Safe D. \& T. Co. v. Salem W. Co. (1899) 94 Fed. 238. Contra: Gorrell v. Greensboro $W$. Co. (I899) I24 N. C. 328 . See further post, "Liability of Water Companies to Third Persons."

${ }^{*}$ For this reason the decision in New Orleans St. J. Assm. v. Magnier, supra, should be disapproved.

${ }^{*}$ Ancrum v. Camden W. Co. (I909) 82 S. C. 284, 2I L. R. A. (N. S.) ro29, 64 S. E. 15I ; Hone v. Presque-Isle W. Co. (I908) I04 Me. 217. Contra, Woodbury v. Tampa Waterworks (1909) 57 Fla. 243 , 2I L. R. A. (N. S.) r034. The cases are very numerous. See Arthur L. Corbin, Liability of Water Comparies (I9I0) I9 YAIE LAW Jourval, 425, where the cases are collected and the possible liability in tort is also considered. Individual citizens are very generally allowed to sue transportation companies and other public service companies on contracts made with the municipality. See note in 49 L. R. A. (N. S.) II66. 
can sue unless the performance by the promisor will discharge some legal or equitable duty of the promisee to the beneficiary. This reason has already been shown to be unsound, as denying rights to all doneebeneficiaries. Also it has been practically abandoned by the courts of New York where it was invented. In all cases of this class the rights of the citizen will vary with the words used by the parties in the express contract; but if a water company contract is in fact for the benefit of third persons they should have the same right of action that other beneficiaries have.

\section{CONTRACTS UNDER SEAL}

The fact that the parties to a contract have executed a formal instrument under seal should not affect the rule as to a third party beneficiary's right to sue. If the right of a beneficiary is recognized at all, it should be recognized in the case of contracts under seal, and there is much authority to this effect. ${ }^{40}$ Many of the courts, however, make the presence of a seal a reason for refusing to recognize a right in the beneficiary. ${ }^{41}$

\section{THE BENEFICIARY'S RIGHT IS NOT BASED ON NOYATION}

It has been held in a few cases that the third party beneficiary must elect between his former debtor and the new promisor, and that a suit against either one, even though it does not result in. collection, will bar any action against the other. ${ }^{22}$

The theory underlying these cases, though not expressed clearly, seems to be that the agreement between the promisor and promisee operates as an offer of a novation to the beneficiary. The chief objection to this theory is that in fact the parties contemplate no such offer and the beneficiary has no reason to believe that in taking advantage of the new contract he is extinguishing his previous rights. If such an offer is in fact made and accepted, the case no longer falls under the present heading. Where a novation is effected, there is a new contract between the promisor and the new promisee, and the latter

\footnotetext{
- Bassett v. Hughes (1877) 53 Wis. 3rg; Hughes v. Oregon R. \& Nav. Co. (1884) II Ore. 437; Coster v. Albany (187I) 43 N. Y. 399; Pond v. New Rochelle W. Co. (1906) 183 N. Y. 330; King v. Scott (1915) 76 W. Va. 58 , 84 S. E. 954 (Code 19r3, sec. 3740); Newberry Land Co. v. Newberry (1897) 95 Va. IIg (Code I904, sec. 24I5). See further I3 C. J. 7Ir, sec. 8I8.

"Harms v. McCormick (1889) 132 Ill. 104; Hendrick v. Lindsey (1876) 93 U. S. 143; Willard v. Wood (1890) 135 U. S. 309; Crowell v. Hospital (1876) 27 N. J. Eq. 650 .

Bohanan v. Pope (1856) 42 Me. 93; Wood v. Moriarty (1887) I5 R. I. 518; Warren v. Batchelder (I845) I6 N: H. 580. See also Aldrick v. Corpenter (I893)-I60 Mass. I66.
} 
is not a beneficiary of a contract between other persons. Instead, he is a pramisee and he has given valuable consideration by discharging his previous debtor.

In the absence of a novation, there seems to be no sufficient reason for holding that the beneficiary's attempt to enforce the duty created by the new contract amounts to a discharge of his previous rights against the promisee. The history of the law of discharge at common law justifies no such holding, and no sufficient reason appears for inducing equity to intervene and to discharge the promisee. In like manner, a suit by the beneficiary against his former debtor should not affect his rights against the new promisor.

Where the beneficiary is not a creditor of the promisee he has no rights to discharge, and the novation theory is wholly inapplicable. Clearly also, the better authority appears to be that the creditorbeneficiary's right against the new promisor is an additional security. ${ }^{43}$ This carries out the real intention of the parties.

\section{CHARACTER OF THE THIRD PARTY'S RIGHT}

The right of a third party beneficiary should be described as a legal right and as a contractual right. It is contractual because the operative facts creating it are acts of offer and acceptance; the party who assumes the duty does so by consenting thereto, and the necessary consideration is the same as that required for any contract. Upon breach of the primary duty by the promisor, the secondary right of the beneficiary may be a right to damages collectible in express assumpsit; the beneficiary is not restricted to an action of debt or indebitatus assumpsit for the amount of the defendant's unjust enrichment. Indeed, in most cases it is held that the promisor need not have received anything at all; it is merely necessary that the promisee shall have given consideration for the promise. There is no particular reason therefore for describing the right and the duty as quasi-contractual. We cannot properly say that the promisor and the third party have made a contract, even though the third party has assented; the contract was made by the promisor and the promisee. The assent of the third party is certainly not the acceptance of an offer, and the third party gives no consideration. Nevertheless, the

- Fischer v. Hope Mut. Life Ins. Co, (I877) 69 N. Y. I6I; Rodenbarger v. Bramfiett (188r) 78 Ind. 213; Davis v. Hardy (I88I) 76 Ind. 272; Gay v. Blanchard (1880) $32 \mathrm{La}$. Ann. 497, 505 ("True, there was no novation of the debt. There was simply an additional obligor bound for it"); Feldman $v$. McGuire (1899) 34 Ore. 309; Smith v. Pfuger (1905) 126 Wis. 253, 105 N. W. 476. See also Poe v. Dixon (18g9) 60 Oh. St. 124

This is necessarily true in mortgagee-beneficiary cases where the court bases the mortgagee's right against the grantee who has assumed the debt upon the doctrine of subrogation. See Hopkins v. Warner (1895) rog Cal. I33. 
right of this party and the duty of the promisor are properly described as contractual.

There is no sufficient reason for describing the third party's right as an equitable right instead of a legal one. The recognition of the third party's right has very largely come about in jurisdictions where there have never been separate courts of common law and of equity; and even in other jurisdictions the right has been enforced in the courts of law as well as in equity. Moreover, in fundamental character, there is no difference between an equitable right and a legal right. Any right, legal or equitable, implies a duty of performance by another, the non-performance being penalized by society. Its existence does not depend upon the number of officials or courts to whom application must be made or upon the complexity of the machinery of enforcement, although these may determine what the secondary and other subsequent rights will be. The term equitable has often meant in the past that application must be made to a chancellor in a particular form called a "bill" and that the societal penalty for nonperformance will be of a particular kind. It no longer has that definite meaning; and if it has such a meaning it is inapplicable in this instance.

In the past, certain rights have been described as equitable because there was a liability to their extinguishment for the benefit of some innocent purchaser. Certain admittedly legal rights were likewise subject to such a liability by the rules of market overt, and hence the existence of such a liability is not the basis of a clear distinction. The right of the third party beneficiary, however, is accompanied by no liabilities that do not accompany all contract rights. The fact that the promisee may have the power of extinguishment is not material on this point. There is no chance here for the application of special bona fide purchaser doctrines. ${ }^{44}$

The accuracy of the foregoing seems not to be doubted in the case of a sole beneficiary. In the case of a creditor-beneficiary, however, the contrary has been maintained, especially in cases where the court overlooked altogether the rights of a sole beneficiary. Thus it has been held that a mortgagee or other creditor can sue the promisor only according to the procedure of a court of equity, and on the theory that the promise is an "asset" of the promisee." Not only

\footnotetext{
* The relation between a beneficiary and the promisor is not a fiduciary one. Attormey General v. American Legion of Honor (1910) 206 Mass. I58.

- Keller v. Ashford (1889) 133 U. S. 610; Green v. Turner (1898) 80 Fed. 41, 86 Fed. 837; Hopkins v. Warner (1895) 109 Cal. 133; Forbes v. Thorpe (IgII) 209 Mass. 570. Observe that this asset theory is different from the one discussed previously. Here the promissory duty is the asset, and is to be reached as an asset of the promisee. The other doctrine supposes the existence of assets in the hands of the promisor. Forbes v. Thorpe, supro, might rest upon both doctrines at once
} 
is such a theory wholly inapplicable to sole beneficiaries, but it is not the theory on which the rights of creditor-beneficiaries have generally been based and it has not been consistently adhered to in any state. ${ }^{40}$ If the promisee has an "asset" in this case it should be available like other assets to his other creditors as well as to the particular creditor who is named as the payee. The present writer has seen no creditor's bill for realizing on this asset brought by. any creditor other than the named payee; but if other creditors could maintain such a bill, it would result in the payee's getting the whole of this asset and still sharing other assets pro rata with the other creditors as to any balance that might be due him. By differentiating this particular creditor from other creditors and this particular "asset" from other assets we are merely recognizing that he has obtained a special right in personam as against the promisor, a right that is created by a contract to which he was not a party. He gains this special right because the contracting parties intended that he should have it, or at least that the performance should go direct to him. To apply the "equitable asset" theory is merely to recognize the third party beneficiary's right under another and mis-descriptive name.

There is no doubt that the chancery procedure had many advantages over that of the common law. This was especially true with respect to its flexibility in the matter of parties to the suit, where more than two parties were involved. In all beneficiary cases there are three interested parties, although the interest of the promisee is not quite the same in sole beneficiary cases as it is in creditor-beneficiary cases. The rights and duties of the three can no doubt be better determined and enforced in one suit to which all are parties than in two or more suits in each of which only two are parties. If the promisor is sued by either the promisee or the third party he should have the power to make the other one a party to the suit. No doubt the procedure of nearly all of our courts is now such as to permit this. Even if not, the case should be regarded merely as one where the promisor has undertaken duties to two persons severally.

\section{THE RIGHTS OF THE PROMISEE}

It was once held in England that where a third party was sole beneficiary, the promisee having no pecuniary interest in the performance, the promisee could maintain no action at law." The same

(1) Sole beneficiaries. Every state recognizes the right of a sole beneficiary in some cases. (2) Statute of limitations. The mortgagee can sue the mortgagor's grantee who assumes the debt, even though the statute of limitations has barred the remedy against the mortgagor. Davis v. Davis (Ig12) I9 Cal. App. 797; Daniels v. Johnson (1900) 129 Cal. 415. (3) Other defenses. It is no defense to the promisor that the promisee may have had a good defense against the plaintiff. Washer v. Independent $M$. \& D. Co. (1904) $142 \mathrm{Cal} .708$.

"Levet v. Hawes ( 1599 ) Cro. Eliz. 619, 652. 
has been held in some cases in the United States.8 ${ }^{48}$ There seems to be no sufficient reason for this. The promisee has paid the consideration and the law should vindicate his right that performance shall take place, even though the damage to the plaintiff is nominal. Where the promisee has a pecuniary interest in performance, as where it is to discharge a debt owed to the third party beneficiary, the promisee certainly can sue the promisor in case of breach. ${ }^{42}$ Thus the latter may be sued by two persons on the same contract; but this is not unjust, because his breach causes an injurious disappointment to two separate persons. By availing himself of modern code procedure or that of equity the promisor can avoid the expense of two actions and the danger of a double recovery.

In states where the beneficiary cannot sue, of course the promisee can, and he can recover the full amount promised. ${ }^{\text {so }}$ The promisee's right is assignable,51 and if the assignment is to the beneficiary the latter can sue as assignee."

POWER OF THE PROMISEE TO RELEASE THE PROMISOR

It is now clear that after the beneficiary has become aware of the contract made for his benefit, and has either acted in reliance on it or has in some manner expressed an assent and approval, the promisee no longer has power to release the promisor from his duty to the beneficiary. ${ }^{53}$ This is true whether the relation of the beneficiary to the promisee is that of donee or that of creditor. No notice of his

* Ayers v. Dixon (1879) 78 N. Y. 318; Adams v. Union Ry. (I899) 21 R. I. I34; Reeves v. Bluff City Bank (I9or) 63 Kan. 789; New Haven v. New Haven E D.R. Co. (I8g2) 62 Conn. 252.

- Meyer v. Hartman (1874) 72 I1l. 442; Tinkler v. Swaynie (I880) 7 Ind. 562; Baldwir v. Emery (I897) 89 Me. 496; Merriam v. Lumber Co. (1877) 23 Minn. 3I4, 322; O'Neill v. American Legion of Honor (1904) 70 N. J. L. 4I0; Langan v. American Legion of Honor (1903) I74 N. Y. 266 (semble); Kelly v. Security Co. (1906) $186 \mathrm{~N}$. Y. I6. The last two cases suggest that the promisee is entitled to a decree for specific performance See further $U . S$. Fidelity \& G. Co. v. U. S. (Ig17) 246 Fed. 433.

${ }^{50}$ Furnas v. Durgin (1876) IIg Mass. 500; Boardman v. Larrabee (I883) $5 \mathrm{I}$ Conn. 39.

The promisor can compel the promisee to pay over the sum collected to the third party beneficiary if the latter holds a mortgage on the promisor's land. Williams v. Fowle (1882) I32 Mass. 385 (semble); Furnas v. Durgir, supro, (semble).

"Hyland v. Crofut (1913) 87 Conn. 49.

- Reed v. Paul (188I) I3I Mass. 129.

Gifford v. Corrigan (188n) II7 N. Y. 257; New York Ins. Co. v. Aitken (I89r) I25 N. Y. 660; Hill v. Hoeldtke (I9r2) I04 Tex. 594, I42 S. W. 87r; 40 L. R. A. (N. S.) 672, with note; Bassett v. Hughes (1877) 43 Wis. 3 I9.

"The person who has made the stipulation cannot revoke it if the third party has declared that he wished to take advantage of it." French Civil Code, sec Ir2r. See also Civ. Code Cal. sec. 1559; Civ. Code S. Dak. sec. rrg3; Rev. L Okla. Igro, sec 895 . 
assent by the beneficiary to the promisor is necessary. ${ }^{54}$ Prior to assent by the beneficiary the promisee may perhaps have the power to release. ${ }^{55}$ Where the third party is the sole beneficiary of the contract the promisee is generally held to have no power whatever to release the promisor, even before the third party is aware of the contract. ${ }^{\text {se }}$

DEFENSES OF THE PROMISOR AS AGAINST THE BENEFICIARY

The beneficiary's rights against the promisor spring from the contract as it was made, and if that contract was in the beginning void for lack of any essential element the third party has no rights. So likewise if the contract was voidable for infancy or insanity or fraud, it is voidable as against the beneficiary. ${ }^{.7}$ If the duty of the promisor is subject to some condition precedent, the correlative right of the beneficiary is likewise conditional. ${ }^{58}$

On the other hand, just as soon as the right of the beneficiary is in existence and beyond the power of the promisee to destroy by a release or rescission, it is also beyond his power to destroy by wrongful acts that would discharge the promisor's duty to himself. Thus a beneficiary can still hold a surety on his bond even though the promisee has discharged such surety's duty to himself by surrendering collateral securities ${ }^{58}$ or by making an alteration of the contract with the principal and without the surety's consent. ${ }^{\circ 0}$

\footnotetext{
Hill v. Hoeldtke, supra.

\$ Trimble v. Strother (1874) 25 Oh. St. 378; Berkshire Life Ins. Co. v. Hutchings (1884) 100 Ind 496; Commercial N. B. v. Kirkwood (I898) I72 I1l. 563; Gilbert v. Sanderson (I881) 56 Iowa, 349.

" Tweeddale v. Tweeddale (1903) II6 Wis. 517; Wetutzke v. Wetutzke (1914) 158 Wis. $305,148 \mathrm{~N}$. W. 1088. The right of the beneficiary of a life insurance policy is generally held to be irrevocable by the insured, even prior to any knowledge or assent by the beneficiary, unless the power of revocation is reserved in the policy. Such a power may of course be reserved.

${ }^{\circ}$ Arnold v. Nichols (I876) 64 N. Y. II7 (the usual rules as to rescission for fraud concerning the return of the consideration, etc., apply); Jenness $v$. Simpson (I9I0) 84 Vt I27, I39; Cohrt v. Koch (I88I) 56 Iowa, 658; Crowe v. Lezvin (1884) 95 N. Y. 423; Dunning v. Leavitt (188I) 85 N. Y. 30 ; Green v. Turner (I898) 80 Fed. 4I, 86 Fed. 837.

${ }^{83}$ Jenness v. Simpson (1910) $84 \mathrm{Vt} .127$, 143; Osborne v. Cabell (I883) 77 Va. 462 (nonperformance or failure of consideration). The case of $O^{\prime} R o u r k e$ v. John Hancock M. L. I. Co. (I902) 23 R. I. 457, is in effect contra, and cannot be supported.

The power of rescission or alteration may be reserved in express terms.

${ }^{\infty}$ Doll v. Crume (1894) 41 Neb. 655; School District v. Livers (I899) 147 Mo. 580.

${ }^{\infty}$ Equitable Sur. Co. v. McMillan (I9r3) 234 U. S. 448; United States v. National Sur. Co. (I899) 92 Fed. 549; Victoria Lumber Co. v. Wells (I916) 139 La. 500; Cowles v. U. S. Fidelity, etc. Co. (1903) 32 Wash. 120; Corn. v. State (1890) I25 Ind. 514; Steffes v. Lemke (1889) 40 Minn. 27.
} 
The duty of the promisor to the beneficiary is quite independent of previous or subsequent relations between the promisee and the beneficiary. ${ }^{\text {B1 }}$

\section{MASSACEUSETTS LAW}

Prior to 1850 the Supreme Court of Massachusetts held in a number of cases that a beneficiary could sue on a contract made by others. ${ }^{82}$ It was largely upon these cases that the decision in Lazurence $v$. Fox $x^{63}$ was based, and they have had an important influence upon the law in the United States to-day. In Mellen $v$. Whipple ${ }^{64}$ it was held that a mortgagee could not sue the grantee of the mortgagor although he had assumed the debt, and Judge Metcalf put all the earlier cases into three classes which he declared to be exceptions to the general rule that no action lies by one not a promisee. Two of these classes were, first, cases where the defendant had received assets which he ought to pay over and, second, cases where the beneficiary was related by blood to the promisee. In Putnam $v$. Field ${ }^{85}$ a liberal application was made of the assets exception. In Exchange Bank v. Rice ${ }^{88}$ a creditor-beneficiary was not allowed to sue, Judge Gray referring to the three classes of exceptions with no very marked approval. Somewhat later all of Judge Metcalf's classes of exceptions seem to have been disapproved, and the cases on which they were based have been declared to be overruled. In Marston $v$. Bigeloze ${ }^{67}$ it was held that a sole beneficiary who was the son of the promisee could not enforce the contract in either law or equity; and in Borden v. Boardman ${ }^{88}$ the assets exception was disregarded and it was held that the beneficiary could not sue unless the parties had

The fraud of the plaintiff as against the promisee is not available as a defense to the promisor. Hurst v. Knight (I914, Tex.) 164 S. W. 1072. The grantee of the mortgagor who has assumed the mortgage debt can set up no defenses against the mortgagee except a satisfaction. Washer $v$. Independent $M$. \& D. Co. (rg04) I42 Cal. 702, 708; Davis v. Davis (1912) ig Cal. App. 797 (statute of limitations); Daniels v. Johnson (1900) I29 Cal. 4I5 (same).

Felton v. Dickinson (1813) 10 Mass. 287 (sole beneficiary and blood relation); Arnold v. Lyman (1821) I7 Mass. 400; Hall v. Marston (1822) I7 Mass. 575; Fitch v. Chandler (1849) 4 Cush. 254; Brewer v. Dyer (185I) 7 Cush. 337 ("the law, operating on the act of the parties, creates the duty, establishes the privity, and implies the promise and obligation").

(1859) 20 N. Y. 268.

${ }^{64}$ (1854) I Gray, 317. See also Dow v. Clark (1856, Mass.) 7 Gray, 198.

( 1870 ) 103 Mass. 556.

* (I87I) 107 Mass. 37. But see Nash v. Commonwealth (I899) 174 Mass. 335, where the exceptions laid down in Mellen $v$. Whipple seem to be approved.

${ }^{\circ}$ (I889) I50 Mass. 45. But see Dean v. American Legion of Honor (1892) I56 Mass. 435, 438; Attorney Gen. v. American Legion of Honor (1910) 206 Mass. $158,166$.

( 1892 ) 157 Mass. 410. A right in the plaintiff in this sort of case has since been recognized as enforceable by a bill in equity. Forbes $v$. Thorpe (rorr) 
created a trust. Fad the magic word "trust" been used, it is clear that the beneficiary's action in "contract" would have been sustained.

Thus the Massachusetts law is supposed to have been brought into harmony with that of England. There is some reason to believe, however, that the Massachusetts court is not wholly satisfied, and numerous decisions very materially limit the rule. In several cases the court has established the existence of "privity" by the liberal use of fiction. Thus where the defendant promised an expectant father to pay a sum of money to the yet unborn child in return for the father's giving the child a certain name it was held that the child could maintain suit on the contract. ${ }^{69}$ In some curious fashion the court was able to convince itself that the child was the promisee and also gave part of the consideration. The child was really a sole (and donee) beneficiary. In like manner an artificial privity in favor of a creditor-beneficiary was discovered by the court in a case where the licensee of a patent had agreed to pay a royalty and had later assigned his license to the defendant "subject to covenants." The licensor was given judgment against the assignee for the royalty due. ${ }^{70}$ Again, where an insurance policy was issued to a mortgagor but the loss was payable to the mortgagee "as its interest may appear," it was held that the mortgagee could sue on the policy in its own name. ${ }^{71}$ In a later case, ${ }^{72}$ the question was raised whether the mortgagee here sued as a-promisee or as an assignee; but so far as appears, the plaintiff was a creditor-beneficiary. ${ }^{73}$ Much earlier, the court had held that a mortgagee-beneficiary could sue the promisor if he held an assignment from the promisee. ${ }^{74}$

209 Mass. 570. And in other cases a trust was held to be created by reason of a statute that bears no obvious indication of any such intent. See Nash $v$. Cosnmonzealth (1899) I74 Mass. 335; George H. Sampson Co. v. Common wealth (1909) 202 Mass. 326.

" Gardner v. Derison (I914) 217 Mass. 492; Eaton v. Libbey (I896) 165 Mass. 218.

"Paper Stock D. Co. v. Boston D. Co. (I888) I47 Mass. 318 . In this case the licensee had an express power to assign; but this is not the power of an agent, much less is it the power to effect a novation.

"Palmer Sav. Bank v. Insurance Co. (1896) 166 Mass. 189. Even if the plaintiff was in fact the promisee, which seems unlikely, it gave no consideration; and in the English courts this fact would deprive the plaintiff of a right to sue. Dunlop v. Selfridge [rgr5] A. C. 847. No doubt this Massachusetts decision was influenced by R. L. 1902, c. II8, sec. 58 ; but that statute does not purport to confer a right of action upon a third party beneficiary. To the same effect is Union Inst. v. Phoenix Ins. Co. (Igo7) Ig6 Mass. 230, where the mortgagor is declared to be the mortgagee's agent.

It Atleborough Bank v. Security Ins. Co. (1897) I68 Mass.-147, 149.

- The Michigan courts regard the mortgagee as a mere third party beneficiary, and deny him a remedy. Mirnock v. Eureka Ins. Co. (I8g2) 90 Mich. 236; Hariford F.I. Co. v. Daverport (I877) 37 Mich. 609.

"Reed v. Paul (1881) 13i Mass. 122 
In a recent case the court has held that a creditor-beneficiary has an equitable claim against the promisor on the theory that the duty of the promisor to the promisee is an asset of the latter that is available to his creditor. ${ }^{73}$ In another case, where $A$ promised $B$ "as trustee" to pay a sum of money to $C$, it was held that B could recover substantial damages and would hold them in trust for $C$. It is to be observed that the promise of $\mathrm{A}$ was not to pay the money to $B$, in trust for $C$, but was to pay the money directly to $C^{76}$

Another method of creating a right in a creditor-beneficiary is to describe the defendant's failure to perform his contract as a tort. ${ }^{7 \pi}$ This method would be used only in cases where the defendant's conduct falls naturally within the tort field, and very likely the other existing facts would be held to create a tort liability in the absence of any contract whatever.

The foregoing cases indicate that the Massachusetts court is quite willing to enforce a duty in the absence of privity in favor of certain kinds of beneficiaries. It may be admitted that this tendency is as yet illustrated only in decisions that are based upon a liberal use of fiction or upon specious distinctions. This is the traditional manner in which a conservative court abandons a previously asserted general rule. $^{78}$

\section{NEW YORK LAW}

The law in New York has already been sufficiently indicated in discussing the rules prevailing throughout the whole country, for the New York courts have had a decisive influence on those prevailing rules. In one respect, however, these courts have been following a course similar to that indicated in Massachusetts. In a number of cases it was laid down that the doctrine of Lawrence $v$. Fox $x^{78}$ was to be restricted to cases exactly parallel thereto, thus allowing creditor-

* Forbes v. Thorpe (Igrr) 209 Mass. 570. See also Clare v. Hatch (1902) I80 Mass. 194. Observe that the existence of this "asset" makes the promisor a debtor and not a trustee. The same is true where a devisee accepts a devise on condition of payment of a legacy to a third party. Felch $v$. Toylor (I832) I3 Pick 133; Adams v. Adams (1867) I4 Allen, 65. See discussion of this "asset" theory supra.

"Grime v. Borden ( 1896 ) I66 Mass. Ig8.

"Phinney v. Boston El. Co. (I909) 201 Mass. 286.

"The contract with the city, whereby the defendant undertook to relieve the city of the performance of its statutory duty, brought the defendant into a relation to those travellers which was the foundation of a legal obligation to provide for their safety."

${ }^{73} \mathrm{By}$ statute the beneficiary of a life insurance policy can sue thereon in his own name. St. I894, C. 225. See also Dean v. American Legion of Honor (1892) 156 Mass. 435; Attorney Gen. v. American Legion of Honor (1910) 206 Mass. I58 ("on a broad construction of the statutes").

To (1859) 20 N. Y. 268. 
beneficiaries to sue and shutting out sole or donee-beneficiaries. The existence of the relation of debtor and creditor between the promisee and the third party was required, or at least the former must owe the latter some "legal or equitable duty" which will be discharged by the promisor's performance. $^{80}$ The New York courts are rapidly destroying this very unsatisfactory limitation, but are doing it by greatly expanding the content of the term "legal or equitable duty." Thus, the general duty that a husband owes to his wife to care for and support her is sufficient to enable her to sue on a promise (made to the husband) to pay her $\$ 50,000.81$ An aunt owes a sufficient duty to her favorite niece when the latter has lived in the aunt's house free of charge and has loved her aunt..82 A resident of a municipality can sue on a contract made between it and the defendant for the benefit of the inhabitants even though the resident could not have sued the municipality in this particular case, inasmuch as the municipality owes some sort of duty to conserve the interests of the inhabitants. ${ }^{83}$ On the same principle, the duty that a labor union owes to its members who pay dues is sufficient to sustain an action by a member as beneficiary. ${ }^{8 t}$

\section{STATUTORY PROVISIONS}

Some states provide by statute that one for whose benefit a promise is made may maintain an action upon the promise. ${ }^{85}$ Third parties

- Durmher थ. Raw (1892) I35 N. Y. 219; Vrooman v. Tumer (1877) 69 N. Y. 280 ; Lorrillard v. Clyde (1890) I22 N. Y. 498. Todd v. Weber (1884) 95 N. Y. 181 is directly contra.

- Bucharar v. Tilden (1899) I58 N. Y. 109; Bouton v. Welch (1902) 170 N. Y. 554 See 2150 DeCicco v. Schweizer (1917, N. Y.) II7 N. E 807 . It may be observed that the payment by the promisor will not discharge the duty of the husband to support his wife.

- Secver v. Ransom (1917, App. Div.) 168 N. Y. Supp. 454

Little v. Banks (:88I) 85 N. Y. 258; Pond v. New Rochelle W. Co. (Ig06) 183 N. Y. 330; Smyth v. New York (1911) 203 N. Y. 106; Rigney ข. New York, etc. R. Co. (1916) 217 N. Y. 31; Schraier v. Bradley Cont. Co., decided Feb. 15, 1918, in N. Y. App. Div. See also City of St. Loxis v. Von Phul (1895) 133 Mo. 561 .

-Gulle v. Barton (1914, N. Y.) 164 App. Div. 293.

- "A contract, made expressly for the benefit of a third person, may be enforced by him at any time before the parties thereto rescind it" Cal Civ. Code, § I559; Idaho Civ. Code, § 2728 ; Mont Civ. Code, \$2103; N. Dak Rev. Codes, \$ 5285; S. Dak Civ. Code, \& 4688.

"If a covenant or promise be made for the sole benefit of a person with whom it is not made, such person may maintain in his own name, any action thereon which he might maintain in case it had been made with him only, and the consideration had moved from him to the party making such covenant or promise" Va Code, \$ 24I5; W. Va. Code, ch. 7I, § 2.

"If there be 2 valid consideration for the promise, it matters not from whom it is moved; the promisee may sustain his action, though a stranger to the consideration." Georgia Code (I9II) \$ 4249

"Any person or persons for whose benefit any contract shall have been made or may hereafter be made, whether such contract be under seal or not, may maintain an action thereon in any court of $12 w$ or equity and may use the same 
can everywhere maintain suit upon statutory official bonds that have been required by law for their protection. ${ }^{80}$ Likewise there are statutes providing that contractors engaged on public works shall give a bond to secure performance and also to protect material men and laborers, a suit by such third persons being expressly or impliedly authorized. ${ }^{87}$

Most states having the reformed procedure provide that all actions shall be brought in the name of the real party in interest. It has been inferred that this provision "places the matter beyond all doubt, for the person for whose benefit the promise is made is certainly the real party in interest." ${ }^{\text {"Bs }}$ In fact, however, this statutory provision does not affect the problem. It was adopted merely for the purpose of creating a more direct and satisfactory procedure for the enforcement of rights already recognized as existing by either law or equity (or by some other system of courts). The question to be determined here is what is the legal operation of the facts of offer and acceptance between promisor and promisee with respect to a third party beneficiary. Do they create in such third party any legal or equitable right? Until we answer this question in the affirmative, it can hardly be said that the beneficiary is "the real party in interest" as that term is used in the procedural statute. And after we have answered it in the affirmative, the beneficiary does not need the aid of this statute to sue in his own name.

as matter of defense to any action brought or to be brought against such person or persons, notwithstanding the consideration of such contract did not move from such person or persons." New Jersey Law 1902, c. 251.

See also French Civil Code, sec II2I. The Louisiana Code is similar to the French. See New Orleans St. J. Assn. v. Magnier (186r) I6 La. Ann. 338;

Gay v. Blarchard (I880) 32 La. Ann. 497.

England and Massachusetts have statutes enabling the beneficiary of an insurance policy to sue. Mass. St 1894, c 225. In Michigan and Connecticut there are similar statutes in favor of mortgagee-beneficiaries. Mich Comp. Laws 1897, sec 519; Conn. G. S. 1902, sec. 587.

* Such bonds are distinguished in Jefferson $v$. Asch (1893) 53 Minn. 446. Coster v. Albany (1871) 43 N. Y. 399, 412 (semble).

- See the Federal statutes, 30 St at L. 906, c. 218; 33 St at L 81r, c. 778. Mass. R. I I902, c. 6, sec. 77; Mass. St. I909, c. 514, sec. 23. Equitable Sur. Co. v. McMillan (IgI3) 234 U. S. 448. Many cases of this sort are cited in note, 49 I. R. A. (N. S.) II75-Ir97.

* Pomeroy, Rem. and Rem. Rights, § I39; Stevers v. Flannagan (I\&gr) 13r Ind. I22; Ellis v. Harrison (I89I) I04 Mo. 270. 